\title{
Chemical Composition and Sensory and Pasting Properties of Blends of Maize-African Yam Bean Seed
}

\author{
Idowu Atinuke* \\ Department of Transport and Tourism Studies, Food Science and Hospitality unit, Redeemer's University, Ede, Nigeria
}

Received: May 21, 2015; Accepted: July 08, 2015; Published: July 20, 2015

*Corresponding author: Idowu Atinuke, Department of Transport and Tourism Studies, Food Science and Hospitality unit, Redeemer's University, Ede, Nigeria, Tel: +2348034525210; E-mail: gb.tinu04@yahoo.com or idowuo@run.edu.ng

\begin{abstract}
This study was designed to improve the nutritional content of maize flour by incorporating African yam bean (an underutilized crop with high nutritional value) and to evaluate its effect on the chemical, sensory and pasting properties of the flour blends. Maize and African yam bean seed were processed into flours at ratios 100:0; 80:20; 70:30; 60:40 and 0:100 and used to produce tuwo, a maize-based meal, its sensory attributes being evaluated. Chemical and pasting properties of the flour blends were determined. Crude protein (9.61$14.71 \%)$, crude fibre (1.34-5.81\%), total ash (1.39-2.09\%) and sugar (4.11-6.01\%) contents increased while fat (4.53-3.94\%), amylase (24.18-11.40\%), starch (66.66-51.15\%) contents and some of the sensory qualities decreased significantly $(p<0.05)$ with increasing quantity of African Yam Bean Flour (AYBF). However, 80:20 flour blend showed no significant difference $(p>0.05)$ from control sample. Among the pasting parameters, final viscosity and break down viscosity reduced while peak viscosity and trough viscosity increased with increasing quantity of AYBF.
\end{abstract}

Keywords: African yam bean seed flour, Maize flour, Proximate composition, Pasting properties, Sensory evaluation

\section{Introduction}

The problem of malnutrition due to deficiency of protein and calories is common in Nigeria. The protein -calories source of vegetable origin have been proposed as a solution to this problem. Maize (Zea mays L.) is commonly used as an inexpensive source of calories in Nigeria and some other countries. Maize is the third most important cereal in the world after rice and wheat and ranks fourth after millet, sorghum and rice in Nigeria [1]. Global statistics for cereal consumption indicate that the average total consumption in the African diet is $291.7 \mathrm{~g}$ per person per day, including an average maize consumption of $106.2 \mathrm{~g}$ per person per day [2]. Maize flour is extensively used in making tamales, tortillas, arepas, fry bread and popular Mexican drink and it is also sprinkled in trays to prevent dishes from sticking. In Nigeria, products from maize include: ogi, tuwo, donkunnu, masa, popcorn, aadun, kokoro, cooked or boiled maize and roasted maize. Some of these products are made from maize flour, which is rich in carbohydrate but low in protein. These products are widely consumed especially among the low income community thus necessitating its enrichment with an inexpensive quality protein.
African Yam Bean (AYB) (Sphenostylis stenocarpa) is a lessutilised tropical legume with high nutritional value. Its protein content is reported to range between 20.2 and 21.2 percent [3]. Amino acid analyses indicate that lysine and methionine levels in the protein are equal to or better than those of soybeans while most of the other essential amino acids correspond to WHO/ FAO recommendations [4]. Moreover, AYB has been reported to also have a high crude fibre content [5]. Although it contains anti-nutritional factors such as haemagglutinins, tannins and oligosaccharides [6], processing destroys most of these factors and the processed products do not give serious health problems [7].

Anti-Nutritional Factors (ANF) in leguminous products are chemical substances present in products although non-toxic but generate adverse physiological responses in animals that consume them. In most cases, ANF interferes with the utilization of nutrients in legume products [8]. Some anti-nutritional factors such as alkaloids, flavonoids, saponins, lectin, trypsin inhibitors, phytate and oxalate have been identified in the seeds of AYB $[9,10,6]$. However, the levels of the various ANF in AYBS were found to be lower than those of cowpea [11]. Apata and Ologhobo [12] reported a complete destruction of trypsin inhibitor and haemaglutinins in some tropical legumes by cooking. Despite the availability and the nutritional importance of this crop, it is still underutilised. AYB has been processed into flour and paste used locally for "moinmoin" (cooked paste) and "akara" (fried bean balls). Enriching maize flour with nutrient-dense African yam bean will help to alleviate protein-energy malnutrition in Nigeria and some other African countries where maize flour are processed into different forms of food products (e.g. snack foods, cooked paste and fried products). Maize flour, like other cereals, is limiting in lysine and tryptophan, but rich in sulphur-containing amino acids, methionine and cystine, the opposite occurring for AYBF [13]. The protein of the maize flour and African yam bean flour thus complement each other's limiting amino acids. High cost of both animal protein and commonly utilized legumes contribute to protein-energy malnutrition. Therefore, the need for less-utilized legumes that are cheaper and rich in protein cannot be overemphasized in the reduction of protein energy malnutrition. This will also offer wider utilization of AYB, and 
offer a better patronage to farmers and industrial producers of AYBF.

Other legumes such as groundnut, soybean, cowpea have been used to improve nutritional contents of maize-based products $[14,15]$. But there is sparse literature on the utilization of AYB to enrich maize flour. Therefore, the current study was carried out;

(i) To determine the effect of AYB flour on the chemical and pasting properties of the maize-AYB flour blends with a potential industrial use

(ii) To evaluate the use of AYB flour in the maize-based meal that is commonly consumed and its consumers' acceptability. The information would contribute to the processing of the maize-AYB flour, thereby improving the utilization of the AYB, creating a novel use for AYB and increasing the nutritional content of food products obtained from the AYB-maize flour blends.

\section{Materials and Methods}

\section{Materials}

Maize (BR-9928-DMR-SY) was obtained from the International Institute of Tropical Agriculture (IITA), Ibadan, Oyo State, Nigeria while the seeds of two varieties of African yam bean were purchased from a retail market (Umuaiha), Abia state, Nigeria and identified as Tss- 9 and Tss-30 at the IITA genetic resource centre.

\section{Sample preparation}

Preliminary analysis was carried out on two varieties of AYB and chosen based on their physical features (attachment to the seed coat) as reported by IITA Genetic Resource Centre. The choice of appropriate cultivar of AYB was made by dehulling manually. It was found that seeds having their seed coats loosely attached to the seeds were more easily dehulled than seeds having their seed coats firmly attached. Therefore, choice of appropriate variety of AYB was made based on its intended use. Loosely attached AYB is required for food products that require dehulling to facilitate easy dehulling process. The study was carried out between July-December, 2012.

Maize samples (BR-9928-DMR-SY) were sorted and milled using $750 \mu \mathrm{m}$ mesh size and packaged in high density $(100 \mu \mathrm{m})$ polyethylene until when needed.AYB (Tss-30) seeds were sorted, weighed, washed and manually dehulled after soaking in water $(1: 5 \mathrm{w} / \mathrm{v})$ for about $4 \mathrm{hr}$ at $29 \pm 2^{\circ} \mathrm{C}$, and then dried in an oven at $60^{\circ} \mathrm{C}$. The dried seeds was milled in a hammer mill (model ED-5 Thomas Wiley, England) and sieved with $500 \mu \mathrm{m}$ mesh size. Parts of the maize flour were substituted with $0,20,30,40$ and $100 \%$ of AYBF by weights. Each blend was properly mixed in a mixer to obtain homogenous samples and packaged separately in airtight plastic containers till needed.

\section{Analytical methods}

Crude protein, ash, crude fibre and crude fat contents were determined using the methods 920.05, 923.03, 963.09 and 920.85, respectively of AOAC [16]. For mineral analysis, atomic absorption spectrophotometer (Buck Scientific model 200A) was used at different wavelength for each mineral element $\mathrm{Cu}$ 324.8, Zn-213,9, Ca-422.7, Fe-248.3, Mg-285.2, Mn-279.5, Na589 and K-766.5nm) [17]. Amylose content was determined following the spectrophotometric method of Julianno 1971 [18] using spectrophotometer (Milton Roy Spectronic 601) at 620nm. Sugars and starch were colorimetrically quantified following the method of Abiodun and Akinoso [19].

The pasting profile of flour sample was studied using a Rapid Visco-Analyzer (RVA) (Newport Scientific Pty. Ltd.) with the aid of a thermocline for windows version 1.1software (1998). The RVA was connected to a PC where the pasting properties and curve were recorded directly. Flour suspension was prepared by addition of the equivalent weight of $3 \mathrm{~g}$ flour to distilled water to make a total of $28 \mathrm{~g}$ suspension in the RVA sample canister. The heating and cooling cycles were automatically programmed in the following manner. The temperature was kept within $60^{\circ} \mathrm{C}$ to $99^{\circ} \mathrm{C}$ while maintaining a rotation speed of $160 \mathrm{rpm}$. The whole cycle was completed within $13 \mathrm{~min}$. The viscosity was expressed in centipoises (cP). The parameters measured (RVA units) were:

Peak viscosity: highest viscosity during the heating stage

Breakdown viscosity: the difference between the peak viscosity and the minimum viscosity at the end of the heating stage

Setback viscosity: the difference between the maximum viscosity during cooling and the minimum viscosity during heating

Final viscosity: the viscosity at the end of the cooling stage

Pasting temperature $\left({ }^{\circ} \mathrm{C}\right)$ : this is the temperature at which there is a sharp increase in viscosity of flour suspension after the commencement of the heating stage.

Peak time (min): time taken for the paste to reach the peak viscosity).

\section{Preparation of maize -AYB meal and sensory evaluation}

The flour blends obtained by varying the proportions of AYBF $(0,20,30$ and $40 \%)$ with maize flour were used to prepare tuwo according to the method described by Aiyeleye and Eleyinmi [20]. Tuwo was made from milled maize enriched with AYB flour and reconstituted into thick paste by boiling water. The thick paste, tuwo produced was subjected to sensory evaluation. Ten semi-trained panelists were selected from the staff and graduate students of IITA, Ibadan, and screened with respect to their interest and ability to differentiate food sensory properties as described by Iwe Iwe [21]. Sensory evaluation room was well-illuminated and the booths were well partitioned to avoid distraction or interference by other panelists. The samples were rated on the following quality attributes: color, taste, palatability, texture, aroma and overall acceptability using a nine point hedonic scale.

\section{Statistical analysis}

All analyses were carried out in triplicate. The mean and 
standard deviation of the data obtained were calculated. The data were evaluated for significant differences in their means with analysis of variance (ANOVA) $(p<0.05)$. Differences between the means were separated using SAS (version 9.2).

\section{Results and Discussion}

\section{Effect of enriching maize flour with African yam bean flour on chemical composition}

Table 1 showed chemical composition of flour blends obtained by varying the proportions of $\operatorname{AYBF}(0,20,30$ and $40 \%)$ with maize flour. Significant $(p<0.05)$ increase in protein content (9.61-14.71\%) was obtained among the flour blends with increasing quantity of AYBF. The increase in protein content obtained is similar to the report of Alozie et al. [5] for wheat-AYB flour blends. This increase in protein content is attributed to the inclusion of AYBF. This can be due to the fact that AYB has been reported to be nutrient-dense, having high protein content [22]. Okafor and Usman [23] also reported higher protein content with increasing AYBF in the breakfast cereal produced from blend of maize, AYB and defatted coconut. The high protein content of AYBF-MF will be of great importance in reducing protein-energy malnutrition resulting from high cost of animal protein and commonly consumed legumes.

Ash content ranged between 1.39 and 2.73\%. This is similar to the values obtained by Amoatey et al. [24] for nutritional composition of the African yam bean compared to some tropical legumes. Significant increase was obtained in the ash contents of the flour blends with increasing quantity of AYBF. The ash contents obtained for the varying proportion of AYBF in maize flour were comparable to the values obtained for Sorghum-AYBF by Okoye et al. [25]. Much higher values were obtained for wheatAYB flour samples by Alozie et al. [5].
Crude fat content of the flour blends (Table 1) obtained ranged from $4.53 \%$ to $2.26 \%$. The value reduced with increasing quantity of AYBF. This may be attributed to low fat content of AYBF reported by earlier authors $[24,26]$. The significant $(p<0.05)$ decrease in fat contents of the flour blends may be of interest to consumers interested in consumption of low fat food products. A similar report was obtained by Ishiwu and Onyeji [27] for instant gruel made from blend of maize starch and African yam bean.

The effect of enriching maize flour with African yam bean flour on the amylose, sugar and starch contents of the MF-AYBF blends are presented in table 2 . Amylase and starch contents of the MF-AYBF blend decreased while sugar contents increased significantly $(p<0.05)$ with higher quantity of AYBF. Amylose is important because it affects water absorption and textural properties of the flour and the resultant products. It was indicated to affect gelatinization, retrogradation, swelling power and enzymatic susceptibility of starch [28]. The amylose content of the blends reduced significantly from $21.41 \%$ (20\% AYBF: $80 \%$ MF blend) to $14.83 \%$ ( $40 \%$ AYBF: $60 \%$ MF blend) as the quantity of AYB flour increased. Amylose is the starch fraction which retrogrades more rapidly due to the tendency of the linear molecule to associate rapidly but amylopectin retrogrades slowly. This implies that paste produced from the 20\%AYBF: $80 \%$ maize flour blend with higher amylose content might retrograde faster than that 60\%MF: 40\%AYBF with low amylose content. Starch retrogradation gives rise to production of resistant starch that is not very digestible; hence, it is of better functionality as it will produce maize meal with low glycemic index which prevents colon cancer [29].

The mineral compositions of MF-AYBF blends were obtained from author's previous work (Idowu, 2015). Sodium, potassium and calcium were the major minerals in the MF-AYBF

Table 1: Proximate composition (\%) of maize and African yam bean blends.

\begin{tabular}{|l|l|l|l|l|}
\hline Blends $^{1}$ & Crude fat & Crude protein & Crude fibre & Ash \\
\hline $100-\mathrm{MF}$ & $4.53 \pm 0.20 \mathrm{a}$ & $9.61 \pm 0.41 \mathrm{e}$ & $1.34 \pm 0.04 \mathrm{a}$ & $1.39 \pm 0.01 \mathrm{e}$ \\
\hline $20-\mathrm{AYBF}$ & $4.17 \pm 0.08 \mathrm{ab}$ & $12.16 \pm 0.12 \mathrm{~d}$ & $2.23 \pm 0.11 \mathrm{~b}$ & $1.79 \pm 0.01 \mathrm{~d}$ \\
\hline $30-\mathrm{AYBF}$ & $3.94 \pm 0.11 \mathrm{ab}$ & $13.72 \pm 0.29 \mathrm{c}$ & $2.68 \pm 0.10 \mathrm{bc}$ & $1.95 \pm 0.01 \mathrm{c}$ \\
\hline $40-\mathrm{AYBF}$ & $3.77 \pm 0.07 \mathrm{~b}$ & $14.71 \pm 0.04 \mathrm{~b}$ & $3.10 \pm 0.15 \mathrm{c}$ & $2.09 \pm 0.03 \mathrm{~b}$ \\
\hline $100-\mathrm{AYBF}$ & $2.26 \pm 0.57 \mathrm{c}$ & $22.73 \pm 0.12 \mathrm{a}$ & $5.81 \pm 0.71 \mathrm{~d}$ & $2.73 \pm 0.02 \mathrm{a}$ \\
\hline
\end{tabular}

Values with the different letters along the column are significantly different at $p<0.05 \mathrm{v}$

${ }^{1} 0 \% \mathrm{AYBF}+100 \% \mathrm{MF} ; 20 \% \mathrm{AYBF}+80 \% \mathrm{MF} ; 30 \% \mathrm{AYBF}+70 \% \mathrm{MF} ; 40 \% \mathrm{AYBF}+60 \% \mathrm{MF} ; 100 \% \mathrm{AYBF}+0 \% \mathrm{MF}$

Table 2: Amylose, sugar and starch contents (\%) of maize and African yam bean blends.

\begin{tabular}{|l|l|l|l|}
\hline Blends $^{1}$ & Amylose & Sugar & Starch \\
\hline $100-$ MF & $24.18 \pm 0.16 \mathrm{a}$ & $4.14 \pm 0.04 \mathrm{~d}$ & $66.66 \pm 0.65 \mathrm{a}$ \\
\hline $20-\mathrm{AYBF}$ & $21.41 \pm 0.16 \mathrm{~b}$ & $4.11 \pm 0.01 \mathrm{~d}$ & $61.97 \pm 0.02 \mathrm{~b}$ \\
\hline $30-\mathrm{AYBF}$ & $18.47 \pm 0.38 \mathrm{c}$ & $4.39 \pm 0.05 \mathrm{c}$ & $58.71 \pm 0.42 \mathrm{c}$ \\
\hline $40-$ AYBF & $14.83 \pm 0.32 \mathrm{~d}$ & $5.25 \pm 0.09 \mathrm{~b}$ & $54.42 \pm 0.38 \mathrm{~d}$ \\
\hline $100-\mathrm{AYBF}$ & $11.40 \pm 0.11 \mathrm{e}$ & $6.01 \pm 0.13 \mathrm{a}$ & $51.15 \pm 0.90 \mathrm{e}$ \\
\hline
\end{tabular}

Values with the different letters along the column are significantly different at $p<0.05$

${ }^{1} 0 \% \mathrm{AYBF}+100 \% \mathrm{MF} ; 20 \% \mathrm{AYBF}+80 \% \mathrm{MF} ; 30 \% \mathrm{AYBF}+70 \% \mathrm{MF} ; 40 \% \mathrm{AYBF}+60 \% \mathrm{MF} ; 100 \% \mathrm{AYBF}+0 \% \mathrm{MF}$ 
Table 3: Mineral composition of maize and African yam bean blends. (Adapted from (Idowu, 2015))

\begin{tabular}{|l|l|l|l|l|l|l|l|l|}
\hline & Ca & Mg & K & Na & Mn & Fe & Cu & Zn \\
\hline Blends ${ }^{1}$ & $(\%)$ & $(\%)$ & $(\%)$ & $(p p m)$ & $(p p m)$ & $(p p m)$ & $(p p m)$ & $(p p m)$ \\
\hline $0 \% A Y B F$ & $0.49 \mathrm{c}$ & $0.12 \mathrm{c}$ & $0.56 \mathrm{~d}$ & $8.24 \mathrm{~d}$ & $12.02 \mathrm{~d}$ & $31.84 \mathrm{c}$ & $0.35 \mathrm{c}$ & $9.16 \mathrm{a}$ \\
\hline $20 \% \mathrm{AYBF}$ & $0.55 \mathrm{~b}$ & $0.15 \mathrm{~b}$ & $0.84 \mathrm{c}$ & $39.23 \mathrm{c}$ & $16.08 \mathrm{c}$ & $32.01 \mathrm{c}$ & $0.88 \mathrm{~b}$ & $9.67 \mathrm{a}$ \\
\hline $30 \% \mathrm{AYBF}$ & $0.58 \mathrm{~b}$ & $0.17 \mathrm{~b}$ & $0.93 \mathrm{~b}$ & $56.40 \mathrm{~b}$ & $16.08 \mathrm{c}$ & $32.02 \mathrm{c}$ & $0.88 \mathrm{~b}$ & $10.12 \mathrm{a}$ \\
\hline $40 \% \mathrm{AYBF}$ & $0.62 \mathrm{~b}$ & $0.16 \mathrm{~b}$ & $0.98 \mathrm{~b}$ & $62.37 \mathrm{~b}$ & $17.34 \mathrm{~b}$ & $47.87 \mathrm{a}$ & $0.88 \mathrm{~b}$ & $9.41 \mathrm{a}$ \\
\hline $100 \% \mathrm{AYBF}$ & $0.74 \mathrm{a}$ & $0.21 \mathrm{a}$ & $1.41 \mathrm{a}$ & $144.78 \mathrm{a}$ & $21.20 \mathrm{a}$ & $38.07 \mathrm{~b}$ & $2.42 \mathrm{a}$ & $8.90 \mathrm{a}$ \\
\hline
\end{tabular}

Values with the different letters along the column are significantly different at $p<0.05$

${ }^{1} 0 \% \mathrm{AYBF}+100 \% \mathrm{MF} ; 20 \% \mathrm{AYBF}+80 \% \mathrm{MF} ; 30 \% \mathrm{AYBF}+70 \% \mathrm{MF} ; 40 \% \mathrm{AYBF}+60 \% \mathrm{MF} ; 100 \% \mathrm{AYBF}+0 \% \mathrm{MF}$

Table 4: Pasting properties of maize and African yam bean blends.

\begin{tabular}{|l|l|l|l|l|l|l|l|}
\hline Blends $^{1}$ & $\begin{array}{l}\text { Peak viscosity } \\
\text { (cP) }\end{array}$ & $\begin{array}{l}\text { Trough1 viscosity } \\
\text { (cP) }\end{array}$ & $\begin{array}{l}\text { Breakdown viscosity } \\
(\mathrm{cP})\end{array}$ & $\begin{array}{l}\text { Final viscosity } \\
(\mathrm{cP})\end{array}$ & $\begin{array}{l}\text { Set back viscosity } \\
(\mathrm{cP})\end{array}$ & $\begin{array}{l}\text { Peak time } \\
(\mathrm{min})\end{array}$ & $\begin{array}{l}\text { Pasting temperature } \\
\left({ }^{\circ} \mathrm{C}\right)\end{array}$ \\
\hline $1100 \%-\mathrm{MF}$ & $479.50 \mathrm{~d}$ & $367.00 \mathrm{~d}$ & $112.50 \mathrm{a}$ & $1654.50 \mathrm{a}$ & $1287.50 \mathrm{a}$ & $7.00 \mathrm{a}$ & $89.80 \mathrm{a}$ \\
\hline $20-\mathrm{AYBF}$ & $481.00 \mathrm{~d}$ & $456.50 \mathrm{c}$ & $104.51 \mathrm{~b}$ & $1363.50 \mathrm{~b}$ & $850.00 \mathrm{~b}$ & $7.00 \mathrm{a}$ & $89.20 \mathrm{a}$ \\
\hline $30-\mathrm{AYBF}$ & $516.00 \mathrm{c}$ & $469.00 \mathrm{c}$ & $101.62 \mathrm{c}$ & $1060.50 \mathrm{c}$ & $604.00 \mathrm{c}$ & $7.00 \mathrm{a}$ & $82.83 \mathrm{~b}$ \\
\hline $40-\mathrm{AYBF}$ & $580.00 \mathrm{~b}$ & $511.00 \mathrm{~b}$ & $99.00 \mathrm{c}$ & $1052.00 \mathrm{c}$ & $583.00 \mathrm{c}$ & $7.00 \mathrm{a}$ & $83.10 \mathrm{~b}$ \\
\hline $100-\mathrm{AYBF}$ & $816.50 \mathrm{a}$ & $720.50 \mathrm{a}$ & $96.00 \mathrm{e}$ & $962.00 \mathrm{~d}$ & $241.50 \mathrm{~d}$ & $5.45 \mathrm{~b}$ & $81.10 \mathrm{c}$ \\
\hline
\end{tabular}

Values with the different letters along the column are significantly different at $p<0.05$

${ }^{1} 0 \% \mathrm{AYBF}+100 \% \mathrm{MF} ; 20 \% \mathrm{AYBF}+80 \% \mathrm{MF} ; 30 \% \mathrm{AYBF}+70 \% \mathrm{MF} ; 40 \% \mathrm{AYBF}+60 \% \mathrm{MF} ; 100 \% \mathrm{AYBF}+0 \% \mathrm{MF}$

Table 5: Sensory evaluation scores of maize and African yam bean blends.

\begin{tabular}{|c|c|c|c|c|}
\hline Parameter & 100-MF & 20-AYBF & 30-AYBF & $40 \% \mathrm{AYBF}$ \\
\hline Colour & $7.47 \mathrm{a}$ & $6.95 a$ & $5.81 b$ & $4.97 \mathrm{~b}$ \\
\hline Taste & 7.21a & $6.89 a$ & $6.71 \mathrm{a}$ & $5.16 \mathrm{~b}$ \\
\hline Palatability & 7.21a & $6.96 \mathrm{a}$ & $5.11 \mathrm{~b}$ & $4.62 \mathrm{~b}$ \\
\hline Texture & $6.11 \mathrm{~b}$ & $6.56 \mathrm{~b}$ & $7.21 \mathrm{a}$ & 7.89a \\
\hline Aroma & 7.11a & $6.89 a$ & $5.32 \mathrm{~b}$ & $4.97 \mathrm{c}$ \\
\hline Overall acceptability & 7.81a & $7.56 a$ & $5.87 \mathrm{~b}$ & $4.67 \mathrm{~b}$ \\
\hline
\end{tabular}

samples(Table 3). With increasing quantity of AYBF, significant $(p<0.05)$ increase for potassium, iron and sodium were obtained, while no significant $(p>0.05)$ difference was obtained for zinc, copper, manganese, calcium and magnesium. Similar report was obtained by Ene-Obong 1992 [30] for mineral composition of AYB flour.

\section{Effect of enriching maize flour with African yam bean flour on pasting properties of maize flour}

According to the RVA patterns, the pasting behavior of AYBFMF blends showed significant difference among the blends (Table 4). Flour sample with $100 \%$ AYBF gave the highest peak viscosity value $(816.50 \mathrm{cp})$, while the $100 \% \mathrm{MF}$ gave the least value. The peak viscosity of MF-AYBF blends was found to increase with increasing quantity of AYBF. The $100 \% \mathrm{MF}$ gave the least trough and the trough value showed significant increase $(p<0.05)$ with increase in quantity of AYBF. Flour sample with $100 \%$ MF had the highest final viscosity, and this final viscosity reduced with increase in quantity of AYBF in the flour blend. This implies that the ability of the flour blends to form a thick paste after gelatinization reduced as the proportion of AYBF increased. This is similar to the report obtained for traditional unfortified maize dough and samples of dough fortified with raw bambara-nut especially at $10 \%$ replacement level [31].

\section{Sensory evaluation Scores of Tuwo produced from AYBF-maize flour blends}

Result from sensory evaluation shown in table 5 indicates that all tuwo samples produced from the various flour blends were generally accepted for all the attributes evaluated as none scored below the minimum acceptable rating of 5 on the 9 point hedonic scale. However, samples with $20 \%$ level of enrichment were generally accepted by the panelists and its sensory values were not significantly $(p>0.05)$ different from those obtained at $0 \%$ level of enrichment which consumers are familiar with. This 
is similar to the report obtained by Abioye 2009 [32] for Soyplantain flour.

\section{Conclusion}

Addition of African yam bean flour to maize flour improved the nutritional content of this cereal, creating a novel use for African yam bean. This fact could be nutritionally advantageous to Nigerians, many of them could hardly afford the expensive protein foods of animal origin and highly utilized legume. Pasting properties of the AYBF-maize flour blends could be an advantage for their industrial uses.

Meal produced from the flour blends were generally accepted by the panelists, thus leading to the production of a tuwo with better nutritional quality as well as a high sensory acceptance which makes it a good prospect for commercial producers of tuwo.

Therefore incorporating African yam bean flour into maize flour is important since the nutritional quality of food products derived from these two raw materials is improved. Moreover, this fact will offer the possibility of use of underutilized legumes, which will help to create new jobs both at farm and at industrial levels.

\section{References}

1. FAO. Maize, rice and wheat: area harvested, production quality and yield. Vol. 25 Foods and Agriculture Organization of the United Nations, Rome, Italy; 2009.

2. World Health Organization. The management of Nutrition in Major Emergencies. Geneva: WHO, United Nations High Commissioner for Refugees, International Federation of Red Cross, World Food Programme; 2000.

3. Eneche HE. Preparation and physico-chemical properties of flours and protein concentrates of raw and germinated African yam bean (Sphenostylis stenocarpa) seeds. Paper presented at the 34th Annual Conference and Scientific meeting of Nutrition Society of Nigeria, Umudike; 2003.

4. Evans IM, Boulter D. Amino-acid composition of seed meals of yam bean (Stenostylis stenocarpa) and lima bean (Phaseolus lunatus). J Sci Food Agric. 1974;25(8): 919-22.

5. Alozie YE, Udofia US, Lawal O, Ani IF. Nutrient composition and Sensory properties of Cake made from wheat and African yam bean flour blends. Journal of Food Technology. 2009; 7(4): 115-118.

6. Okeola OG, Machuka J. Biological effects of African yam bean lectin on Clavigralla tomentosicollis (Hemiptera:coreidae). J Econ Entomol. 2001; 94(3): 724-9.

7. Idowu AO. Nutritional, sensory and storage properties of snack produced from Maize (Zea mays Linn) and African yam bean seed (Sphenostylis stenocarpa Hocht Ex A. Rich). 2014.

8. Nwokolo EA. Nutrient assessment of African yam bean (Sphenostylis stenocarpa) and bambara groundnut (Voandzea subterrannea). Journal of Food Science and Agriculture. 1987; 41(2): 123-129. DOI: $10.1002 /$ jsfa.2740410205.

9. Ajibade SR, Balogun MO, Afolabi OO, Ajomale KO, Fasoyiro SB. Genetic variation in nutritive and anti nutritive content of African yam bean. Tropical Science. 2006; 45(4): 144-8. DOI: 10.1002/ts.14.
10. Azuzu IU, Undie A. Some observation on the toxic effect of the seed extract of Sphenostylis stenocarpa (Hochst ex.A. Rich. Harms) on intestinal muscle. Plant Food Human Nutrition. 1986; 36(1): 3-9. DOI: 10.1007/BF01091747.

11. Aletor VA, Aladetimi 00. Compositional evaluation of some cowpea varieties and some under-utilised edible legumes in Nigeria. Nahrung. 1989; 33(10): 999-1007.

12. Apata DF, Ologhobo AD. Trypsin inhibitor and other anti-nutritional factors in Tropical legume seeds. Tropical Science. 1997; 37: 52-59.

13. Adewale D. African yam beans: a food security crop? IITA research guide(4). 2010.

14.Uzo-Peters PI, Arisa NU, Lawrence CO, Osondu NS, Adelaja A. Effect of partially defatted soybeans or groundnut cake flours on proximate and sensory characteristics of kokoro. African Journal of Food Science. 2008; 2: 98-101.

15. Omueti 0, Morton ID. Development by Extrusion of Soybari snack stiicks: a nutritionally improved Soya-maize products base on the Nigerian snack (kokoro). Int J Food Sci Nutr. 1996; 47(1): 5-13.

16. AOAC. Official methods of chemical analysis. Association of Official Analytical Chemists. $15^{\text {th }}$ edn. Washington: USA; 1990.

17. Novozamsky I, Houba VJG, Van ECK, Van VW. Plant nitrogen and phosphorus in plant tissue, novel digestion technique for multielement. Communication in soil science and plant analysis 1983; 14(3): 239-248. DOI: 10.1080/00103628309367359.

18. Perez CM, Julianno BO. Modification of the Simplified Amylose Test for Milled Rice. Cereal Science Today. 1978; 30(12): 424-26.

19. Abiodun OA, Akinoso R. Effect of harvesting periods on the chemical and pasting properties of trifoliate yam flour. Food Chem. 2014; 142: 159-65. doi: 10.1016/j.foodchem.2013.07.015.

20. Aiyeleye FB, Eleyinmi AF. Improved traditional processing techniques for selected tropical food commodities. FADCOL Educational press. Akure, Ondo State: Nigeria; 1997.

21. Iwe MO. A handbook of sensory methods and analysis. Ro-jaunt Commercial services Ltd. Enugu; Nigeria; 2002.

22. Eneche HE. Enrichment of Starchy flours with African yam bean protein concentrate. Nigerian Journal of Nutrition and Science. 2005; 26: 30-37.

23. Okafor GI, Usman GO. Production and evaluation of breakfast cereals from blends of African yam bean (Sphenostylis stenocarpa) and maize (Zea mays) and fefatted coconut (Cocus nucifera). Journal of Food Processing and Preservation. 2013; 38(3): 1037-43. doi: 10:1111/ jfpp.12060.

24. Aboagye LM, Klu GYP, Bansa D, Kumaga FK, Aboagye LM, BennetLartey SO, Gamedoagbao DK. African yam bean (Sphenostylis stenocarpa): A neglected crop in Ghana. West African Journal of Applied Ecology. 2000; 1: 53-60.

25. Okoye JI, Ezigbo VO, Animalu IL. Development and Quality Evaluation of weaning food fortified with African yam bean (Sphenostylis stenocarpa) flour. Continental Journal of Agricultural Science. 2010; 4: 1-6.

26. Edem DO, Amugo CI, Eka OU. Chemical composition of Yam bean (Sphenostylis stenocarpa). Tropical Science. 1990; 30: 59-63.

27. Ishiwu CN, Onyeji AC. Properties of an instant gruel based on blend of maize (Zea mays L) starch, African yam bean (Sphenostylis stenocarpa) flour and soybean (Glycine max) flour. Nigerian Journal 
of Nutrition and Science. 2004; 25: 16-19.

28. Gerard C, Barron P, Planchot V, Colonna P. Amylose determination in genetically modified starches. Carbohydrate polymer. 2001; 44(1): 19-27.

29. Smolin LA, Grosvenor MB. Nutrition: Science and Applications, $3^{\text {rd }}$ edn. Wiley Global Education; Florida: 2012.

30. Ene-Obong HN, Carnovale EA. Comparison of the proximate, mineral composition of lesser known legumes in Nigeria. Food Chemistry.
1992; 43(3): 169-75.

31. Mbata IT, Ikenebomeh MJ, Ahonkhai I. Improving the quality and Nutritional status of Maize fermented meal by fortification with bambara nut. The Internet Journal of Microbiology. 2005; 2(2): 107112.

32. Abioye VF, Ade Omowaye BIO, Babarinde GO and Adesigbin MK. Chemical, physico-chemical and sensory properties of soy-plantain flour. African Journal of Food Science. 2009; 5(4): 176-180. 